Environment Conservation Journal 14(1\&2)113-119, 2013

ISSN 0972-3099 (Print) 2278-5124 (Online)

Abstracted and Indexed

\title{
Ambient air quality of Katra Town (J\&K): A Study with Reference to atmospheric particulates
}

\author{
Anil K. Raina $\bowtie$ and Anita Sharma
}

Received: 22.01.2013

Accepted: 28.03.2013

\begin{abstract}
The monitoring of ambient air quality of Katra (one of the important town of Jammu from economic as well as religious point of view), at selected locations of residential areas, commercial areas and traffic crossings with respect to particulate matter (both respirable and non-respirable) has been conducted for a period of two years i.e. July 2010 - June 2012. Large variations in ambient particulate matter concentrations have been observed throughout the study period. Seasonally, the particulate matter exhibited low values during monsoon period and high values during post-monsoon period. The concentration of particulates (both respirable and non-respirable) in post monsoon season exceeded the concentrations than that of other seasons at most of the sites, thereby signifying the impact of local factors on pollutant concentrations, besides the impact of meteorological factors. Higher concentrations have been recorded in the year 20112012 as compared to $2010-2011$ at all the sites except traffic crossings.
\end{abstract}

Keywords Ambient air quality, Katra town, RSPM, TSPM, seasonal variations.

\section{Introduction}

Mankind's relations with the environment are becoming more complex with the scientific and industrial revolution as a result environment has become the most obvious sink for various pollutants like sulphur dioxide, nitrogen dioxide, hydrocarbons, carbon monoxide and particulates released during various activities (Raina and Sharma, 2006). RSPM (both $\mathrm{PM}_{10}$ and $\mathrm{PM}_{2.5}$ ), $\mathrm{SO}_{2}$, $\mathrm{NO}_{2}, \mathrm{CO}, \mathrm{O}_{3}$ and Lead) has been identified by United State Environment Protection Agency (USEPA) as six criteria pollutants which have to be considered important from public health viewpoint. Air borne particulate matter is the recent focus of the world community as it penetrates the respiratory system of human beings and causes many disorders. It has also been shown through worldwide studies that the urban population is at risk due to elevated levels of particulate matter in the ambient air (Mohanraj and Azeez, 2004). Therefore, it is important to know particulate matter concentration in the ambient air. Both respirable and non-respirable particulate matter is major ubiquitous particulate contaminants of the air.

\section{Author's Address}

Department of Environmental Sciences,

University of Jammu, Jammu

E-mail-anilkraina@yahoo.com
Several activities like construction and demolition, vehicular traffic, movement of public, meteorological conditions etc. contribute for the particulate matter. The adverse effects of air borne particulates upon health are well recognised. These particles can penetrate deep into the respiratory system and studies indicate that smaller the particle, more severe the health impacts (Dockery and Pope, 1994). Short term exposure to particulate matter contributes to respiratory symptoms, adverse effects on cardio-vascular system, increase in medication usage, hospital admissions and mortality. Effects related to long term exposure include increase in Chronic Obstructive Pulmonary Disease (COPD) and reduction in lung function in adults and children (Dockery, 2002). Atmospheric particulate matter is the major air pollutant in India. Several studies have been carried out in India to highlight the air quality status in relation to total suspended particulate matter (Sharma et al., 2005; Bhaskar and Mehta, 2010; Dahabi et al., 2010; Vanadeep and Krishnaiah, 2011). In many Indian cities, the level of particulate pollutants in the ambient air has been found to be above the permissible limits (Mohanraj and Azeez, 2004). In Katra (latitude $32^{0} 59^{\prime} \mathrm{N}$, longitude $74^{0} 55^{\prime} \mathrm{E}$, 
altitude $2840 \mathrm{ft}$ ) , religiously and economically important town of Jammu, construction and demolition for providing better infrastructure to tourists is a growing trend. Also, the number of vehicles along with other sources of pollution is constantly increasing because of continuous increase in the number of tourists. So far, no systematic study has been carried out to monitor the concentration of atmospheric particulate matter in the ambient air of the Katra town.

\section{Material and Methods}

To estimate the ambient air quality with respect to particulate matter, three residential areas (Paharganj, Gopal Nagar and Keshav Nagar), three commercial areas (Main bazaar, Chintamani and Hospital road) and three traffic crossings (Bus stand, Railway road and Serli) have been identified after a thorough survey of the town. Air sampling was carried out by using High Volume Air Sampler (Envirotech Model $460 \mathrm{BL}$ ) based on the method IS 5182, part IV. The sampling instrument was fixed at a breathing height of $1.5-2 \mathrm{~m}$ above the ground level. The sampling has been carried out on monthly basis during day time for 8 hours for a period of 2 years i.e. July 2010 to June 2012. The respirable fraction (RSPM or $\mathrm{PM}_{10}$ ) was collected on pre-weighed Whatman glass microfiber filter paper (G/F, $20.3 \times 25.4 \mathrm{~cm})$. Particles in the size range of $(10-100 \mu \mathrm{m})$ were collected in a separate sampling bottle placed under hopper assembly of the cyclone fitted in the APM-460 BL sampler to separate the coarse particles from air stream before filtering it on the glass microfiber filter. The filter paper and sampling bottle were re-weighed after sampling in order to determine the mass of particles collected. Finally, the TSPM (Total suspended particulate matter) concentration was calculated by summing up the RSPM $\left(\mathrm{PM}_{10}\right)$ and NRSPM $\left(\mathrm{PM}_{10}\right.$ 100) concentrations.

\section{Results and Discussion}

The monthly data on particulate matter concentration (RSPM, NRSPM and TSPM) of residential areas, commercial areas and traffic crossings for the study period has been depicted in Table 1 . In the residential areas, the average concentration of RSPM , NRSPM and TSPM during the first year of study period (July 2010 to June 2011) varies between $20.0 \mu \mathrm{g} / \mathrm{m}^{3}$ to $93.65 \mu \mathrm{g} / \mathrm{m}^{3}, \quad 39.97 \mu \mathrm{g} / \mathrm{m}^{3}$ to $252.51 \mu \mathrm{g} / \mathrm{m}^{3}$ and $59.97 \mu \mathrm{g} / \mathrm{m}^{3}$ to $329.82 \mu \mathrm{g} / \mathrm{m}^{3}$, respectively whereas during the second year (July 2011 to June 2012), their values varies between $23.79 \mu \mathrm{g} / \mathrm{m}^{3}$ to 113.03 $\mu \mathrm{g} / \mathrm{m}^{3}, \quad 42.49 \mu \mathrm{g} / \mathrm{m}^{3}$ to $225.01 \mu \mathrm{g} / \mathrm{m}^{3}$ and 67.19 $\mu \mathrm{g} / \mathrm{m}^{3}$ to $337.52 \mu \mathrm{g} / \mathrm{m}^{3}$, respectively. In the commercial areas, the average concentration of RSPM, NRSPM and TSPM varies between 29.47 $\mu \mathrm{g} / \mathrm{m}^{3}$ to $187.47 \mu \mathrm{g} / \mathrm{m}^{3}, 74.02 \mu \mathrm{g} / \mathrm{m}^{3}$ to $301.09 \mu / \mathrm{m}^{3}$ and $112.6 \mu \mathrm{g} / \mathrm{m}^{3}$ to $477.86 \mu \mathrm{g} / \mathrm{m}^{3}$, respectively, during the first year and between $35.03 \mu \mathrm{g} / \mathrm{m}^{3}$ to $194.05 \mu \mathrm{g} / \mathrm{m}^{3}, 81.09 \mu \mathrm{g} / \mathrm{m}^{3}$ to $491.01 \mu \mathrm{g} / \mathrm{m}^{3}$ and $127.36 \mu \mathrm{g} / \mathrm{m}^{3}$ to $685.06 \mu \mathrm{g} / \mathrm{m}^{3}$, respectively, during second year. At traffic crossings, the average concentration of RSPM, NRSPM and TSPM during the first year of study period varies between 40.32 $\mu \mathrm{g} / \mathrm{m}^{3}$ to $293.02 \mu \mathrm{g} / \mathrm{m}^{3}, 91.73 \mu \mathrm{g} / \mathrm{m}^{3}$ to $848.29 \mu \mathrm{g} / \mathrm{m}^{3}$ and $132.05 \mu \mathrm{g} / \mathrm{m}^{3}$ to $1060.89 \mu \mathrm{g} / \mathrm{m}^{3}$, respectively and between $10.40 \mu \mathrm{g} / \mathrm{m}^{3}$ to $288.11,100.85 \mu \mathrm{g} / \mathrm{m}^{3}$ to $863.91 \mu \mathrm{g} / \mathrm{m}^{3}$ and $145.23 \mu \mathrm{g} / \mathrm{m}^{3}$ to 1152.02 $\mu \mathrm{g} / \mathrm{m}^{3}$, respectively during the second year. The concentration of particulates has been observed to be always higher in traffic crossings and commercial areas in comparison to residential areas. According to Vanadeep and Krishnaiah (2011), the traffic generated emissions are accounting for more than $50 \%$ of the total particulate matter emissions in the urban areas. The number of vehicles in Jammu is increasing tremendously due to the growing tendency of the public to own a vehicle and this has resulted in the increase in vehicular population. The growing number of vehicles, outdated engine designs, defective and deficient road network, erratic driving patterns and congested slow moving traffic contribute to tremendous increase in air pollution problems in most of the developing countries like India (Dutta and Meena, 2008). At traffic crossings, higher levels of particulates have been recorded at Railway Road, which can be attributed to heavy traffic flow especially heavy vehicles (buses and trucks) and re-suspension of road dust. The quality of road pavement and streets is very poor at this location and a large quantity of dust accumulates in the air by wind and traffic movement. Vehicles 
Ambient air quality of Katra Town

Table 1: Monthly values of RSPM, NRSPM and TSPM $\left(\mu \mathrm{g} / \mathrm{m}^{3}\right)$ at different sites during 2010-2012

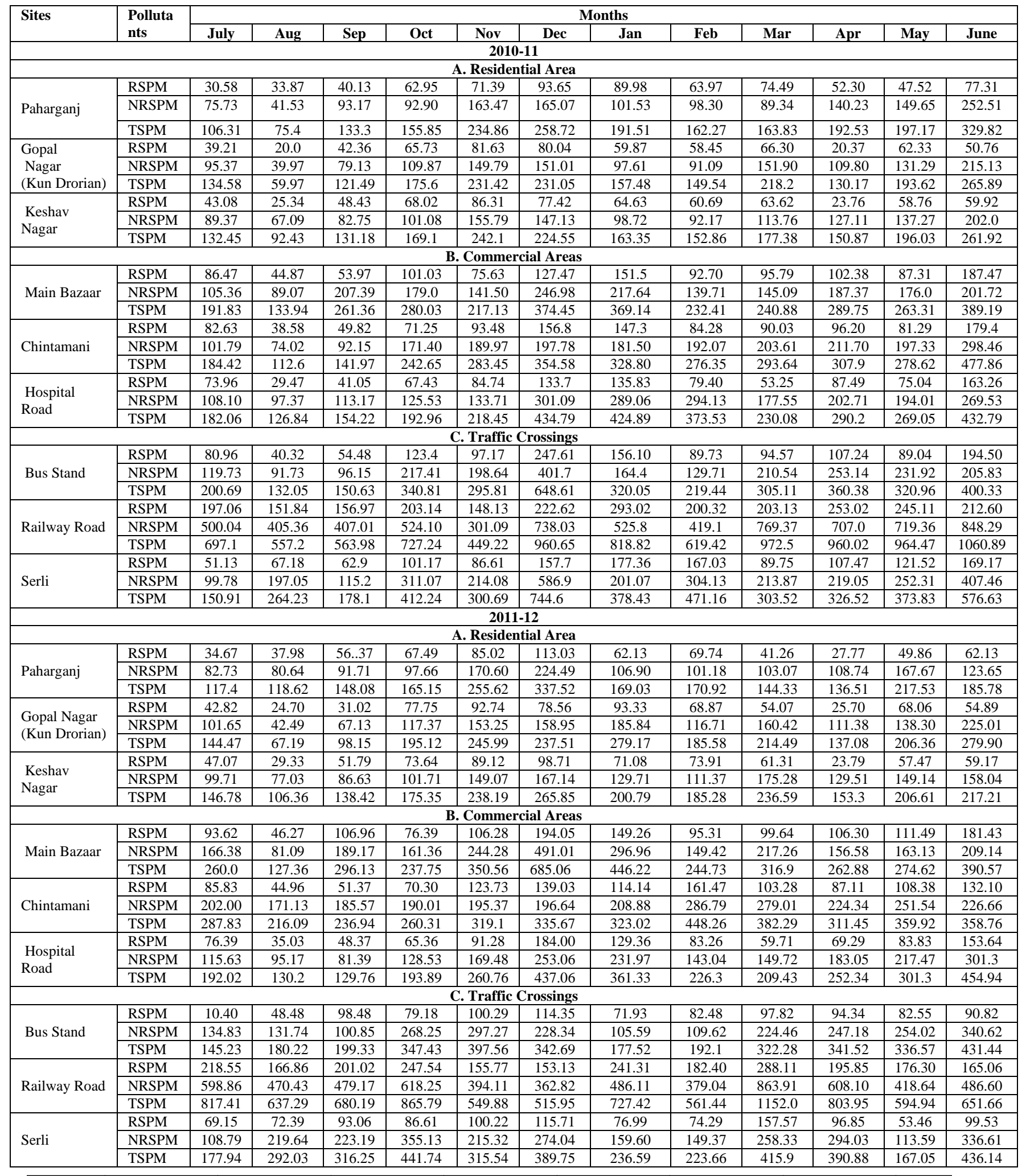

115

Environment Conservation Journal 
with large engine size emit more pollutant (Mathew,2012).There were more construction activities because of newly developed railway station near this site which has also resulted in higher emissions of coarse particulate matter. Namedo and Bell, (2005) has also reported higher emissions of coarse particulate matter due to construction activities. Also, indiscriminate burning and dumping of municipal solid waste in open near this point contributes towards higher concentrations of particulate matter.In commercial area, the maximum concentration of particulates has been recorded at Main bazaar. Heavy traffic flow, frequent traffic jams and slow speed of vehicles, presence of auto-rickshaw stand for passengers etc. contributes for the higher particulate matter concentrations at this site. Traffic jams are common at this site as the roads are narrow and congested and also because of heavy rush of tourist for shopping, free flow of traffic is often interrupted. Tom and Mathew (2012) have also reported the increase in emissions of particulate matter with the decreasing speed of vehicles. In addition to vehicular exhaust, re-suspension of road dust, presence of small restaurants, use of coal and wood as a fuel in nearby eateries (dhabhas), bakery shops and prominent shopping complexes for tourists as well as for locals and large number of construction activities also increases the concentration of particulate matter. Use of diesel-powered generators during frequent electricity supply cuts, also contribute for the increase in concentration. Moreover, tall buildings on both sides of the road prevent wind speeds from being sufficiently strong to be able to disperse the pollutants.Ambient particulate concentrations has been recorded lowest in residential areas as compared to other

study sites; however in this category lowest concentrations have been recorded in Gopal Nagar which may be attributed to comparatively lower number of inhabitants, less construction, lesser number of vehicles and presence of vegetation around this site. This area has not been commercialized as compared to other sites.During the study period, most of the times, the concentration of particulates (both respirable and non-respirable) at commercial sites and traffic crossings has been found to be above the permissible limits as stipulated by CPCB (Table 3).Month wise variation of total suspended particulate matter concentration has shown highest values in March, $2011\left(1060.89 \mu \mathrm{g} / \mathrm{m}^{3}\right)$ and June, $2012\left(1152.02 \mu \mathrm{g} / \mathrm{m}^{3}\right)$, respectively. The higher concentration of particulates in March has been attributed to Navratra festival being held at Katra , increased number of tourists in navratras and strengthening of winds associated with monsoon currents whereas higher concentrations in the month of June may be attributed to increase in vehicular traffic because of heavy rush of tourists in summer holidays and also the increased construction activities due to favourable weather conditions. The lowest concentration of total suspended particulate matter has been recorded in the month of August, $2010\left(59.97 \mu \mathrm{g} / \mathrm{m}^{3}\right)$ and July, $2011\left(10.40 \mu \mathrm{g} / \mathrm{m}^{3}\right)$, respectively. Heavy rainfall during this period has resulted in washing out of pollutants and cleaning the atmosphere. Seasonal variation of RSPM and TSPM show low value during the monsoon period at all the selected locations and high values during post monsoon, winter and summer season (Table 4).

Table 3: National ambient air quality standards , CPCB

\begin{tabular}{|l|c|c|}
\hline \multirow{2}{*}{ Location Type } & \multicolumn{2}{|c|}{ Permissible limits in $\mathbf{~} \mathbf{g} / \mathbf{m}^{\mathbf{3}}$} \\
\cline { 2 - 3 } & RSPM (PM $\left._{\mathbf{1 0}}\right)$ & SPM \\
\hline Industrial & $100^{*}$ & $500^{* *}$ \\
\hline Residential & $100^{*}$ & $200^{* *}$ \\
\hline Ecologically sensitive areas & $100^{*}$ & $100^{* *}$ \\
\hline
\end{tabular}

* denotes revised standards (2009)

** denotes old standards since SPM parameter has been excluded in the revised standards. 
Table 4: Seasonal average of RSPM, NRSPM and TSPM at different sites during the study period

\begin{tabular}{|c|c|c|c|c|c|}
\hline \multirow[t]{2}{*}{ Sites } & \multirow[t]{2}{*}{ Pollutant } & \multicolumn{4}{|c|}{ Seasons } \\
\hline & & Summer & Monsoon & Post-Monsoon & Winter \\
\hline \multicolumn{6}{|c|}{ A. Residential Areas } \\
\hline \multirow[t]{3}{*}{ Paharganj } & RSPM & 48.86 & 46.63 & 82.25 & 71.45 \\
\hline & NRSPM & 126.45 & 105.20 & 152.36 & 101.97 \\
\hline & TSPM & 175.31 & 151.83 & 234.62 & 173.43 \\
\hline \multirow{3}{*}{$\begin{array}{l}\text { Gopal Nagar (Kun } \\
\text { Drorian) }\end{array}$} & RSPM & 49.46 & 38.21 & 79.40 & 70.13 \\
\hline & NRSPM & 133.84 & 108.23 & 140.04 & 122.81 \\
\hline & TSPM & 183.31 & 146.45 & 219.57 & 192.94 \\
\hline \multirow[t]{3}{*}{ Keshav Nagar } & RSPM & 48.11 & 45.51 & 82.20 & 67.57 \\
\hline & NRSPM & 138.67 & 107.82 & 136.95 & 107.99 \\
\hline & TSPM & 186.79 & 153.34 & 219.18 & 175.57 \\
\hline \multicolumn{6}{|c|}{ B. Commercial Areas } \\
\hline \multirow[t]{3}{*}{ Main Bazaar } & RSPM & 100.48 & 100.13 & 113.47 & 122.2 \\
\hline & NRSPM & 174.19 & 156.16 & 244.02 & 200.92 \\
\hline & TSPM & 274.22 & 256.29 & 357.49 & 323.12 \\
\hline \multirow{3}{*}{ Chintamani } & RSPM & 94.38 & 83.08 & 109.09 & 126.79 \\
\hline & NRSPM & 227.92 & 168.97 & 190.19 & 217.30 \\
\hline & TSPM & 322.3 & 252.06 & 299.29 & 344.10 \\
\hline \multirow[t]{3}{*}{ Hospital Road } & RSPM & 71.43 & 77.64 & 104.41 & 106.96 \\
\hline & NRSPM & 187.41 & 147.70 & 185.23 & 239.54 \\
\hline & TSPM & 258.73 & 225.35 & 289.64 & 346.51 \\
\hline \multicolumn{6}{|c|}{ C. Traffic Crossings } \\
\hline \multirow[t]{3}{*}{ Bus Stand } & RSPM & 94.26 & 77.3 & 127.0 & 100.05 \\
\hline & NRSPM & 236.87 & 152.68 & 268.6 & 127.3 \\
\hline & TSPM & 331.13 & 229.99 & 395.48 & 227.27 \\
\hline \multirow[t]{3}{*}{ Railway Road } & RSPM & 226.91 & 183.74 & 188.38 & 229.26 \\
\hline & NRSPM & 681.06 & 524.51 & 489.7 & 452.51 \\
\hline & TSPM & 907.98 & 708.21 & 678.12 & 681.78 \\
\hline \multirow[t]{3}{*}{ Serli } & RSPM & 104.43 & 85.56 & 108.0 & 123.91 \\
\hline & NRSPM & 225.19 & 213.46 & 326.09 & 203.54 \\
\hline & TSPM & 329.61 & 229.02 & 434.09 & 327.46 \\
\hline
\end{tabular}

The relatively high values in the summer season especially after March can be attributed to the strengthening of winds associated with the monsoon currents. The strong and medium winds creates turbulent conditions and local disturbances in the environment which cause frequent dust storms and hazy conditions that build up high particulate matter levels in the ambient air. The summer maxima owe to a great increase in vehicular traffic because of heavy rush of tourists in summer holidays and also the increased construction activities due to favourable weather conditions. Low humidity and higher wind speeds also aggravate the condition and contribute towards the higher concentration of particulates in summer. The sharp fall in particulate concentration in the monsoon season shows the effect of rain on clearing the atmosphere. Particulate matter 
absorbed by clouds and /or raindrops get washed down during rainfall (Ravindra et al., 2003) which contributes to the cleaning of atmosphere. In rainy season due to humidity, the suspended particulates present in the atmosphere also settle down. Because of rainfall, the soil become damprestricting the possibility of soil derived particles being released. Low values of particulates during the monsoon period is also in line with the findings of Mishra et al., (2011) and Bhaskar and Mehta, (2010). During post- monsoon season, their concentration has been found to be higher. The reason may be increased October heat and very heavy flow of tourists and vehicles due to Navratras and festival activities like Dusshera and Diwali.The concentration of these pollutants has increased significantly in 2011-2012 as compared to 2010-2011 in commercial and residential areas while at two of the traffic crossings, their concentrations has shown a decrease in 2011-2012 as compared to 2010-2011. The decrease in concentration at two of the selected traffic crossings has resulted due to the diversion of routes of inter-state buses during this period of heavy rush.Dispersion and transportation of particulates is also affected by meteorological parameters. Several studies have revealed that meteorological parameters like wind speed, relative humidity, precipitation and temperature affect the distribution of particulates (Sharma et al., 2005; Bhaskar and Mehta, 2010 and Mishra et al., 2011). Relative humidity, ambient temperature and precipitation are inversely correlated with particulates. Low wind speed inhibit dilution whereas high wind speed lead to increased soil dust mobilisation (Mkoma and Mjemah, 2011). Reduced dispersion on account of low wind velocity and low temperature contributes towards the high concentration of particulates (respirable and nonrespirable) in winter. Burning of fuel wood and fossil fuel on a large scale for cooking and for heating in winter also contributes to the problem. Moreover, winter received much less rainfall in comparison to other seasons. As a result, removal of atmospheric particulates by wet scavenging is much reduced during this period. Similar results have also been reported by Sharma et al., (2005); Bhaskar and Mehta (2010); Dahabi et al., (2010) and Majumder et al., (2012).Thus, the present study revealed the significant seasonal variations of particulate matter concentrations at all the selected locations with higher concentrations during post monsoon, winter and summer season and lower during monsoon season. Their concentrations have often crossed the National Ambient Air Quality Standards as stipulated by CPCB at many sites. Continuous rise in concentration of particulates reflect the ever increasing trend of vehicular population and development activities in the town.

\section{References}

Bhaskar, B.V. and Mehta, V.M., 2010. Atmospheric particulate pollutants and their relationship with meteorology in Ahmedabad. Aerosol and Air Quality Research, 10 : 301-315.

Bureau of Indian Standards (BIS), 1973. Method of measurement of air pollutant- suspended particulate matter, 5182, part IV, Indian Standard Institute, New Delhi.

Colbeck, I., Nasir Z.A., Ahmad S. and Ali Z., 2011. Exposure to $\mathrm{PM}_{10}$, $\mathrm{PM}_{2.5}, \mathrm{PM}_{1}$ and $\mathrm{CO}$ on roads in Lahore, Pakistan. Aerosol and Air Quality Research, 11: 689-695.

CPCB, 2001. Respirable particulate matter and its health effects. Central pollution control board, New Delhi.

Dahabi,I.A., Al-Zu’bi,Y., Rimawi,O. and Al-Zu’bi,J., 2010. The relationship between total suspended particulate matter (TSP) and different climatic factors: A case of Jordan. Journal of Food , Agriculture and Environment, 8(1) : 308-311.

Dockery D.W. and Pope C.A., 1994. Acute respiratory effects of particulate air pollution. Annual Review Public Health, 15: 107132.

Dockery, D.W., 2002. Epidemiologic evidence of cardiovascular effects of particulate air pollution. Environmental Health Perspectives, 109 : 483-486.

Dominic,D., Latif,M.T., Juahir,H., Aris,A.Z. and Zain,S.M., 2012. An assessment of influence of meteorological factors on $\mathrm{PM}_{10}$ and $\mathrm{NO}_{2}$ at selected stations in Malaysia. Sustainable. Environmental Research, 22(5) : 305-315.

Dutta, S. and Meena, M.K., 2008. Air quality status at selected locations in Ajmer city, Rajasthan. Indian Journal of Environment and Ecoplanning , 15 (1-2) : 111-114.

Gangwar K.K and Deepali, 2010. Impact of Ardh-Kumbh festival on concentration level of suspended particulate matter and respirable suspended particulate matter in Haridwar, India. New York Science Journal, 3(5): 50-53.

Gordian M.E. and Morris S.,1996. Particulate air pollution and respiratory diseases in Anchorage, Alaska. Environment Health Perspectives, 104 : 290-297.

Goswami,P. and Baruah,J., 2008. Simulation of daily variation of suspended particulate matter over Delhi : Relative roles of 
vehicular emissions, dust and domestic appliances. American Meteorological Society, 136 : 3597-3607.

Gupta D. and Vidya A., 1994. Ambient air quality of Shimla town with reference to suspended particulate matter. Indian Journal of Environmental Health., 36 : 400-402.

Gurtu D., Vaidya M.and Gajghate D.G., 2001. World scenario of particulate matter, $\mathrm{NO}_{2}$ and $\mathrm{SO}_{2}$ : A review. Indian Journal of Environmental Protection, 21 (2) :683-695.

Joshi, P.C., Swami A., and Gangwar K.K., 2006. Air quality monitoring at two selected traffic junctions in the city of Haridwar. Himalayan Journal of Environmental Zoology, 20(2) : 219-221

Joshi, G. and Jain, C., 2000. Suspended particulates in the ambient air at the roadside of Indore city. Pollution Research, 19(3) : 365367.

Karar ,K., Gupta, A.K., Kumar, A. and Biswas, A.K., 2006. Seasonal variations of $\mathrm{PM}_{10}$ and TSP in residential and industrial sites in an urban area of Kolkata, India. Environmental Monitoring and Assessment, 118 : 369-381.

Majumder, A.K., Nazmul Islam, K.M., Bajracharya, R.M. and Carter, W.S., 2012. Assessment of occupational and ambient air quality of traffic police personnel of the Kathmandu valley, Nepal; in view of atmospheric particulate matter concentration $\left(\mathrm{PM}_{10}\right)$. Atmospheric Pollution Research, 3 : 132-142.

Mathew ,T.V. 2012. Fuel consumption and emission studies. Traffic Engineering and Management : 1-27.

Mishra, S. , Chauhan, C., Chelani, A., Kumar, A. and Chalapati,Rao, C.V., 2011. Modelling the effect of wind speed and wind direction on RSPM concentration in ambient air : A case study at urban areas in central India. International Journal of Environmental Protection, 1(3) : 9-14.

Mkoma, S.L. and Mjemah, I.C., 2011. Influence of meteorology on ambient air quality in Morogoro, Tanzania. International Journal of Environmental Science, 1(6) : 1107-1115.

Mohanraj R. and Azeez P.A., 2004. Health effects of air-borne particulate matter and the Indian scenario. Current Science, 87(6) : 741-748.

Mohanraj, R. and Azeez P.A., 2005. Urban development and particulate air pollution in Coimbatore city, India. International Journal of Environment Studies, 62(1) : 69-78.
Namedo, A. and Bell, M.C., 2005. Characteristics and health implications of fine and coarse particulates at roadside, urban background and rural sites in UK. Environment International, 31 : 1181- 1187 .

Nanda, S.N. and Tiwari, T.N., 2001. Concentration of SPM in the Burla-Hirakud- Sambalpur region (Orissa). Indian Journal of Environmental Protection, 21(3): 193-202.

Pope III, C.A. and Dockery,D.W., 2006. Health effects of fine particulate air pollution : Lines that connect. Air and Waste Management Association, 56 : 709-742.

Rajasekhar RVJ, Samy IK, Sridhar M. and Muthusubramanian P., 1999. Estimation of suspended particulate matter in the ambient air of Madurai city by sedimentation and filtration methods. Indian Journal of Environmental Protection, 21(8) : 673-676.

Raina, A.K. and Sharma, A., 2006. Assessment of air pollution and its impact on the leaves of some plant species. Pollution Research, 25(3): 543-547.

Ravindra, K., Mor, S., Ameena, Kamyotra, J.S. and Kaushik, C.P. 2003. Variation in spatial pattern of criteria air pollutant before and during initial rain of monsoon. Environment Monitoring and Assessment, Vol. 87: 145-153.

Rua A., Gimeno L. and Hernandez E., 1998. Trend, seasonal variation and sources of suspended particulate matter (SPM) in Spain. Toxicological Environmental Chemistry, 70: 181-193.

Sharma R. and Parvez S., 2003. Study of seasonal variation in ambient particulates of Durg city. Indian Journal of Environmental Protection, 23 (8) : 893-896.

Sharma R., Pervez Y. and Pervez S., 2005. Seasonal evaluation and spatial variability of suspended particulate matter in the vicinity of a large coal-fired power station in India - A case study. Environment Monitoring and Assessment, 102: 1-13.

Thambavani, D.S. and Maheswari, J., 2013. A combined analysis of airborne particulate pollutants exposure and its potential risk. Chemical Science Transactions, 2(2) : 000-000.

Vanadeep, K. and Krishnaiah, M. 2011. Air quality monitoring at residential areas in and around Tirupati- a well known pilgrimage site in India. Indian Journal of Science and Technology, 4(11) : $1517-1531$.

Vasanthy, M. and Jeganathan ,M., 2008. Monitoring of air quality in terms of respirable particulate matter- A case study. Journal of Industrial Pollution Control, 24(1); 53-55. 